ISSN 0258-7122 (Print), 2408-8293 (Online)

Bangladesh J. Agril. Res. 43(3): 499-512, September 2018

\title{
CHARACTERIZATION AND GENETIC DIVERSITY OF BRINJAL GERMPLASM
}

\author{
M. T. ISLAM ${ }^{1}$, R. A. CHHANDA ${ }^{2}$, N. PERVIN ${ }^{3}$ \\ M. A. HOSSAIN ${ }^{4}$ AND R. U. CHOWDHURY ${ }^{5}$
}

\begin{abstract}
The experiment was carried out in a non replicated design with 40 accessions of brinjal (Solanum melongena L.) at Plant Genetic Resources Centre (PGRC), BARI Gazipur to characterize and study the genetic diversity and identify the useful traits. Each accession of nine plants was grown in a 3 X $2 \mathrm{~m}$ size plot. The accessions were collected from 16 districts of Bangladesh. Two to four classes were found for plant growth habit, leaf blade lobing, leaf prickles, flower colour, fruit shape, fruit apex shape and fruit colour distribution. The accessions exhibited $64 \%$ straight, $13 \%$ both slightly curved and curved, and $10 \%$ snaked shaped edible fruit along with 55\% purple and $45 \%$ green fruit. Fruit length of accessions ranged from 5 to $31.23 \mathrm{~cm}$, breadth 2.4 to $10.6 \mathrm{~cm}$, weight 13 to 95.2 $\mathrm{g}$ and 3 to 30 fruits per plant. The accessions were grouped into five clusters. The inter and intra cluster distances ranged from 4.01 to 8.32 and 0.94 to 1.36 , respectively. Accessions collected from the same districts felt into different clusters. The results obtained by $\mathrm{D}^{2}$ analysis were also confirmed by canonical analysis. Crosses BD-7327 (Rangpur) of cluster II with BD-9954 (Chittagong) of Cluster-III and BD-7319 (Panchagarh) of Cluster-I with BD-11732 (Bandarban) of cluster $\mathrm{V}$, could be performed for obtaining wider variability in the segregating generations. The breeders could use the selected accessions for varietal improvement of brinjal.
\end{abstract}

Keywords: Solanum melongena, cluster, characterization, diversity and Bangladesh.

\section{Introduction}

Brinjal (Solanum melongena L.) is the second important vegetable in Bangladesh. It is a good source of minerals and vitamins. The consumption of fruits and vegetables is important from the nutritional point of view and many consumers are now conscious about the health benefits of foods. The current nutritional condition of third world and some emerging countries like Bangladesh is a matter of concern as many people are suffering from malnutrition (Begum et al., 2017). Brinjal can play a significant role in this case and can mitigate the nutritional shortage to some extent. Considering the potentiality of this crop, there is a need for improvement and to develop varieties for specific agro-

${ }_{1,2 \& 3}$ Plant Genetic Resources Centre, Bangladesh Agricultural Research Institute (BARI), Joydebpur, Gazipur-1701, ${ }^{4}$ Support Service Wing, BARI, Joydebpur, Gazipur-1701, ${ }^{5}$ Regional Agricultural Research Station (RARS), BARI, Burirhat Rangpur. Bangladesh. 
ecological conditions and also for specific end use. It is grown on approximately 46,566 hectares of land across the country both in winter and summer season, yielding an average of 7.30 ton per hectare and a total production of about 3 , 39,874 ton (BBS, 2011). The crop is highly diverse for fruit shape, size and colour in Bangladesh due to the Indian gene centre (Hawks, 1983). BARI released 20 varieties of brinjal including two hybrid and four transgenic varieties for cultivation in Bangladesh. The fruit and shoot borer resistant, trangeneic varieties are 'BARI Bt Bagun-1', 'BARI Bt Bagun-2', 'BARI Bt Bagun-3' and 'BARI Bt Bagun-4' (Azad et al., 2017). Bangladesh Agricultural University released two brinjal varieties. Different seed companies released more than 60 varieties including hybrid (SCA, 2018). In addition, a lot of landraces are cultivated all over the country. PGRC of BARI conserved 282 accessions in the genebank. Systematic research such as collection, conservation, characterization and evaluation, and utilization of brinjal germplasm has been done at PGRC of BARI. Few studies on both morpho-genetic and molecular level have been done in different countries but few or none reports included accessions from Bangladesh (Murali et al., 2017; Sunseri et al., 2010; Demir et al., 2010; Islam and Uddin 2009, Khorsheduzzaman et al., 2008; Kumer et al., 2008). Characterization and evaluation of plant germplasm is imperative for categorization of germplasm and identification of desirable genotypes carried out in precision fields under sufficient growth and plant protection conditions for utilization in breeding programs (Upadhyaya et al., 2008). Before these resources can be exploited, they should be systematically evaluated to assess genetic diversity. Until a collection has been properly evaluated and its attributes become known to breeders, it has little practical use (Thomas and Mathur, 1991). Such a situation is just like a library where none of the books are catalogued. Therefore, the current piece of research will help to identify suitable germplasm of brinjal which can be used to develop desirable varieties. The specific purpose of this study was to characterize and to study the genetic diversity and identify the potential accessions for varietal improvement of brinjal in Bangladesh.

\section{Materials and Methods}

The experiment was conducted at PGRC of BARI, Joydebpur, Gazipur during September 2013 to May 2014 at $24.00^{\circ} \mathrm{N}$ latitude, $90.26^{\circ} \mathrm{E}$ longitudes and 8.40 $\mathrm{m}$ above sea level. The soil of the experimental field was silty clay having a $\mathrm{pH}$ of 6.5. Forty accessions including BARI Bagun-1 (Uttara) was used as check variety. The accessions were collected from 16 districts such as Panchagarh (3 accessions), Thakurgaon (2), Dinajpur (1), Rangpur (7), Pabna (3), Rajshahi (6), Chapai Nawabganj (1), Magura (1), Barisal (1), Tangail (1), Jamalpur (2), Sherpur (1), Chittagong (3), Bandarban (4), Rangamati (3) and Moulvibazar (1) of Bangladesh from $20^{\circ} 35^{\prime}$ to $26^{\circ} 75^{\prime} \mathrm{N}$ latitude and $88^{\circ} 03^{\prime}$ to $92^{\circ} 75^{\prime} \mathrm{E}$ longitude. Seedlings were raised in the seed bed containing a mixture of sandy-loamy soil 
and decomposed cowdung on 27 September 2013. Main field was prepared 10 days before transplanting the seedlings. The recommended doses of manure and fertilizers such as 5 ton/ha cowdung, $120 \mathrm{~kg} \mathrm{~N}, 36 \mathrm{~kg} \mathrm{P}, 90 \mathrm{Kg} \mathrm{K}, 15 \mathrm{~kg} \mathrm{~S}$ and $2.0 \mathrm{~kg} / \mathrm{ha} \mathrm{Zn}$ in the form of urea, triple super phosphate, murate of potash, gypsum and zincsulphate (monohydrate), respectively were applied in the experimental field (FRG, 2012). The full doses of cowdung, TSP, gypsum and zincsulphate were applied during land preparation before one week of transplanting. Urea and MP were applied in the three equal splits at 21, 35 and 50 days after transplanting as ring method around the plant followed by irrigation (10-15 days interval during dry season). The experiment was conducted in a non replicated design. The unit plot size was $3 \times 2 \mathrm{~m}$ and nine plants were accommodated in a plot with a plant spacing of $75 \mathrm{~cm}$ apart and row to row distance of $100 \mathrm{~cm}$. The seedlings at the age of 52 days were transplanted on 18 November 2013. The insecticide admire $(0.5 \mathrm{ml}$ per litre $)$ was applied for controlling aphids. Twenty-four observations on qualitative (12) and quantitative (12) characters were classified into descriptor states (Table 1) as per Descriptors for Eggplant (IBPGR, 1990). Range, mean, standard deviation and coefficient of variation of quantitative characters were calculated (Table 2). Principal Component Analysis, Principal Coordinate Analysis, Canonical Vector analysis and Cluster analysis were performed with Genstat 5 software.

\section{Results and Discussion}

\section{(i) Characterization of brinjal}

Sixty percent green and $20 \%$ both light violet and violet cotyledon were found among the 40 accessions of brinjal (Table 1). Plant growth habit, $48 \%$ intermediate, $45 \%$ upright and $7 \%$ prostrate were exhibited at vegetative stage. Begum et al. (2017) found erect, semi-erect and spreading growth habit in genetic variability study of brinjal. Leaf blade lobing, 60\% weak, 37\% intermediate and 3\% strong along with $62 \%$ acute, 33\% very acute and 5\% intermediate leaf blade tip angle were observed among the accessions. Solaimana et al. (2015) reported three types of leaf blade lobing and leaf blade tip angle. Leaf prickles were absent in $25 \%$ accessions. The remaining accessions produced $40 \%$ very few, $25 \%$ few and 5\% both intermediate and many prickles. Very few $(<20)$ to few $(20-50)$ number of leaf hairs were noted. The accessions exhibited $53 \%$ light violet, $37 \%$ bluish violet and $10 \%$ pale violet flowers. Hassan et al. (2015) found light purple and purple flower among 22 brinjal accessions. The maximum, $64 \%$ accessions produced straight edible fruit followed by $13 \%$ both slightly curved and curved, and the minimum, $10 \%$ accessions showed snake shaped fruit curvature. About half way from base to tip (77\% accessions) and about three quarter from base to tip (23\%) for fruit shape were found. Fruit apex shape, $38 \%$ depressed, $34 \%$ rounded and $28 \%$ protruded was found. Edible fruit colour, 55\% purple and $45 \%$ green along with $47 \%$ uniform, $30 \%$ stripped and 
23\% mottled fruit colour distribution were exhibited (Table 1, Fig.1). Similar types of fruit curvature and fruit apex shape were reported by Solaimana et al. (2015). But more fruit colour variation was noted by Hassan et al. (2015) and Begum et al. (2017). Solaimana et al. (2015) found uniform and stripped fruit colour distribution. Different qualitative variations were found due to the different types of descriptor used in data recording, different growing region and diverse type of accessions were used in the experiments.

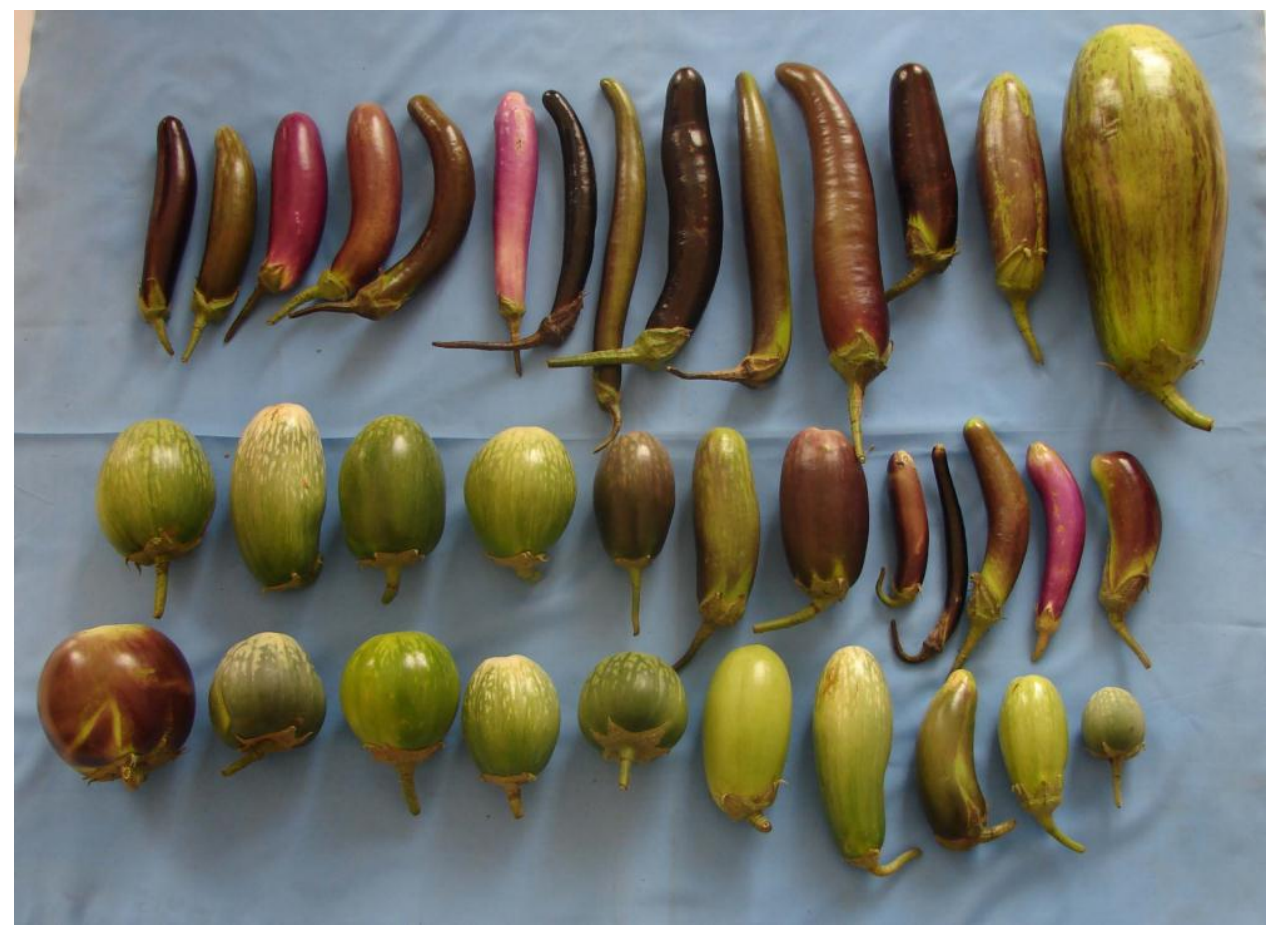

Fig. 1. Diversity of brinjal accessions at PGRC of BARI Bangladesh.

\section{(ii) Descriptive statistics of quantitative character}

The extent of diversity in respect to 12 characters in different accessions of brinjal are measured in terms of range, mean, standard deviation and co-efficient of variations (Table 2). A wide variation was observed among the different characters studied. The highest number of primary branches per plant was exhibited in BD-10154 (9.8) while the lowest 4.9 was observed in BD-7327. The accessions exhibited 50.8 to $96.2 \mathrm{~cm}$ plant height, 64.3 to $119.7 \mathrm{~cm}$ plant breadth, 11.7 to $23.4 \mathrm{~cm}$ leaf blade length and 7.8 to $13.3 \mathrm{~cm}$ leaf blade width. This indicated that the range of five characters were approximately two times larger than their minimum limit. Solaimana et al. (2015) found 4 to 7 branches, 45.6 to $87.4 \mathrm{~cm}$ plant height, 7.05 to $22.06 \mathrm{~cm}$ leaf blade length among the brinjal genotypes. The accessions produced first flower on 86 days (BD-9766) to 115 
days (BD-11730) and days to 1st edible fruiting stage on 107 (BD-9766) to 139 (BD-11733) days. Earlier fruit harvest (45 to 128 days) was found by Solaimana et al. (2015). The accessions exhibited fruit length from $5 \mathrm{~cm}$ (BD-11738) to 31.2 $\mathrm{cm}$ (BD-10158). Among them, 54\% long, 23\% intermediate, $18 \%$ very long and $5 \%$ short fruits were found. Fruit breadth ranged from 2.40 (BD-7320) to 10.60 $\mathrm{cm}$ (BD-11726) where $42 \%$ intermediate, $33 \%$ long and $25 \%$ short were noted. The accessions produced $40 \%$ medium, $35 \%$ low and $25 \%$ high fruit weight ranging from 13 (BD-7321) to 95.20 g (BD-7319) (Table 2 and Table 3). The highest number of fruits per plant was obtained from BD-9955 (30) and the lowest from BD-11737 (3). Hasan et al. (2015) found 1.8 to $22.9 \mathrm{~cm}$ fruit length, 1.3 to $12.4 \mathrm{~cm}$ fruit breadth and 12.1 to $214.0 \mathrm{~g}$ fruit weight and Solaimana et al. (2015) found 7.15 to $31.56 \mathrm{~cm}$ fruit length, 2.6 to $9.0 \mathrm{~cm}$ fruit breadth and 35.5 to $313.30 \mathrm{~g}$ fruit weight in their study. 100-seed weight ranged from 0.19 to $0.48 \mathrm{~g}$. More or less similar results were observed by Hassan et al. (2015) and Begum et al. (2017). The quantitative descriptors for individual accessions are presented in Table 2. The maximum co-efficient of variation was found in number of fruits per plant $(57.99 \%)$ followed by $47.23 \%$ fruit length, $47.21 \%$ fruit weight, $43.71 \%$ fruit breadth, $16.67 \%$ plant breadth, $15.50 \%$ plant height, $15.10 \%$ number of primary branches and the lowest, $5.48 \%$ was found in days to first edible fruiting stage.

Table 1. Qualitative variation of different characters in brinjal

\begin{tabular}{l|l|c|c}
\hline Name of descriptor & Descriptor state & $\begin{array}{c}\text { Number of } \\
\text { accession }\end{array}$ & $\begin{array}{c}\text { Percent of } \\
\text { accession }\end{array}$ \\
\hline \multirow{3}{*}{ Cotyledon colour } & Green & 24 & 60 \\
& Light violet & 8 & 20 \\
& Violet & 8 & 20 \\
\hline \multirow{3}{*}{ Plant growth habit } & Intermediate & 19 & 48 \\
& Upright & 18 & 45 \\
& Prostrate & 3 & 7 \\
\hline \multirow{3}{*}{ Leaf blade lobing } & Weak & 24 & 60 \\
& Intermediate & 15 & 37 \\
& Strong & 1 & 3 \\
\hline & Acute & 25 & 62 \\
Leaf blade tip angle & Very acute & 13 & 33 \\
& Intermediate & 2 & 5 \\
\hline \multirow{3}{*}{ No. of leaf prickles } & Very few & 16 & 40 \\
& None & 10 & 25 \\
& Few & 10 & 25 \\
& Intermediate & 2 & 5 \\
& Many & 2 & 5 \\
\hline
\end{tabular}




\begin{tabular}{|c|c|c|c|}
\hline Name of descriptor & Descriptor state & $\begin{array}{c}\text { Number of } \\
\text { accession }\end{array}$ & $\begin{array}{l}\text { Percent of } \\
\text { accession }\end{array}$ \\
\hline \multirow{2}{*}{ No. of leaf hairs } & Very few & 35 & 87 \\
\hline & Few & 5 & 13 \\
\hline \multirow{3}{*}{ Flower colour } & Light violet & 21 & 53 \\
\hline & Bluish violet & 15 & 37 \\
\hline & Pale violet & 4 & 10 \\
\hline \multirow{4}{*}{ Fruit curvature } & Straight & 26 & 64 \\
\hline & Curved & 5 & 13 \\
\hline & Slightly curved & 5 & 13 \\
\hline & Snake shaped & 4 & 10 \\
\hline \multirow{2}{*}{ Fruit shape } & $\begin{array}{l}\text { About half way from base } \\
\text { to tip }\end{array}$ & 31 & 77 \\
\hline & $\begin{array}{l}\text { About three quarter from } \\
\text { base to tip }\end{array}$ & 9 & 23 \\
\hline \multirow{3}{*}{ Fruit apex shape } & Depressed & 15 & 38 \\
\hline & Rounded & 14 & 34 \\
\hline & Protruded & 11 & 28 \\
\hline \multirow[t]{2}{*}{ Fruit colour } & Purple & 22 & 55 \\
\hline & Green & 18 & 45 \\
\hline \multirow{3}{*}{$\begin{array}{l}\text { Fruit colour } \\
\text { distribution }\end{array}$} & Uniform & 19 & 47 \\
\hline & Stripped & 12 & 30 \\
\hline & Mottled & 9 & 23 \\
\hline
\end{tabular}

(iii) Genetic diversity in brinjal

The 40 accessions collected from 16 districts were arranged into 5 clusters on the basis of genetic diversity (Table 4). Number of accessions in each cluster ranged from 5 (Clusters-III) to 10 (Cluster-II and Cluster-IV). Cluster I contained 7 accessions of district Panchagarh, Thakurgoan, Sherpur, Chittagong, Bandarban and Rangamati. Cluster II was composed of the 10 accessions from Rangpur, Pabna, Rajshahi and Tangail. Cluster III formed with the 5 accessions of Rangpur, Pabna, Chittagong, Rangamati and Bandarban. Cluster IV was composed of the 10 accessions from Panchagarh, Dinajpur, Rangpur, Barisal, Jamalpur, Moulvibazar and Rangamati. Cluster V consisted of 8 accessions from Thakurgoan, Rajshahi, Chapai nawabganj, Pabna, Magura, Chittagong and Bandarban. 'BARI Bagun-1' (Uttara, BD-7781) was grouped in cluster V. Accessions collected from the same geographic origin (districts) were distributed into different clusters. In many cases, the accessions from different districts were grouped in the same cluster indicating their close affinity. This result suggested 


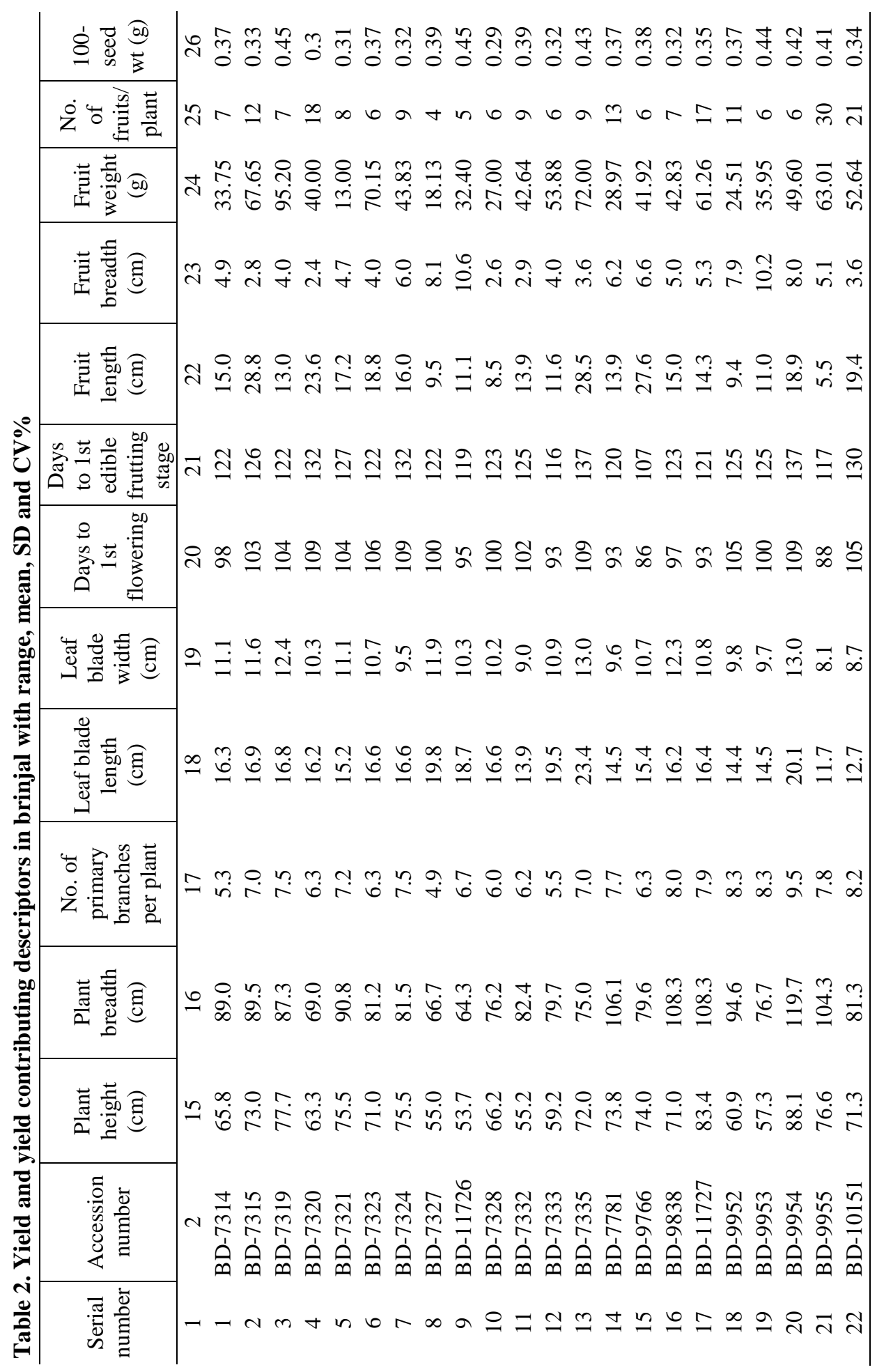




\begin{tabular}{|c|c|c|}
\hline 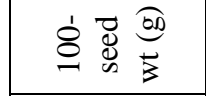 & 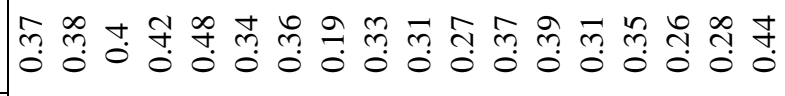 & 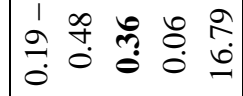 \\
\hline 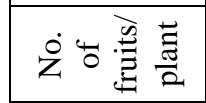 & สำ은 n & 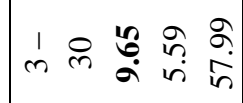 \\
\hline 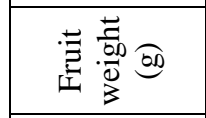 & 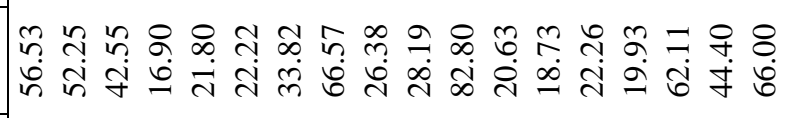 & l \\
\hline 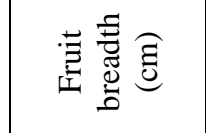 & 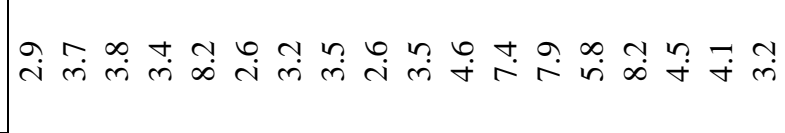 & 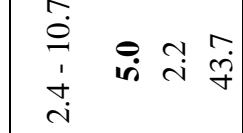 \\
\hline 害害总 & 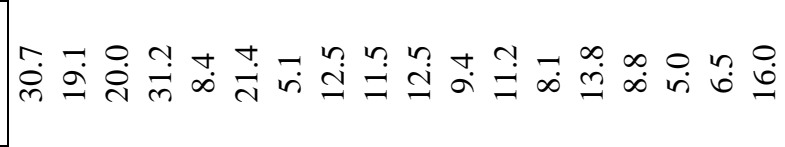 & 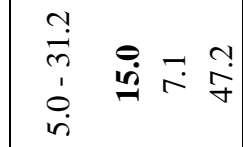 \\
\hline 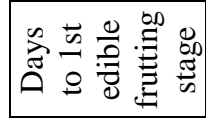 & 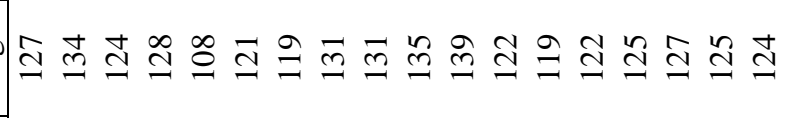 & I \\
\hline 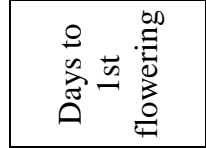 & 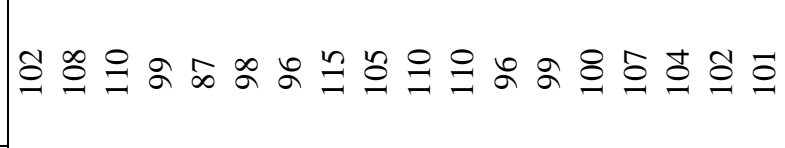 & $\begin{array}{llll}1 & \curvearrowleft & \approx & \infty \\
\infty & 0 \\
0 & 0\end{array}$ \\
\hline 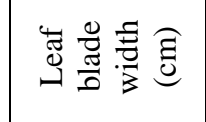 & 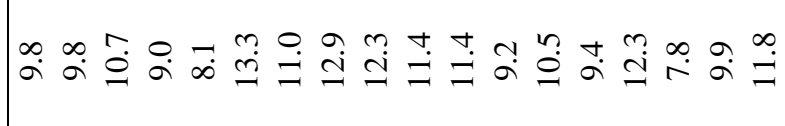 & 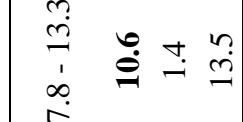 \\
\hline 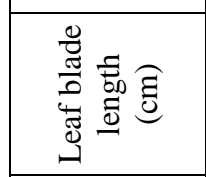 & 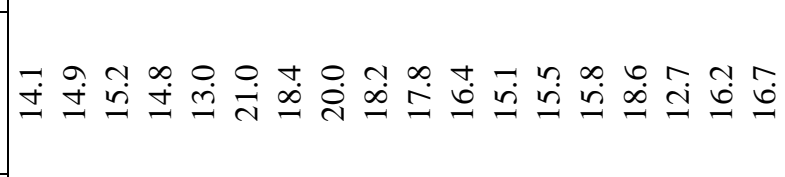 & 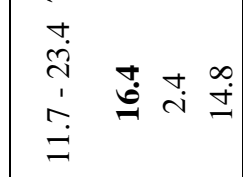 \\
\hline 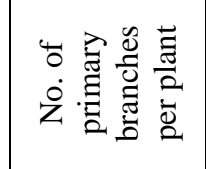 & 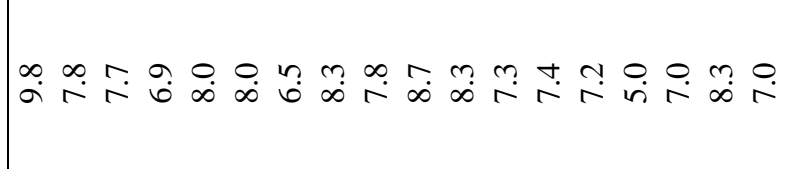 & 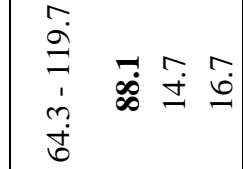 \\
\hline 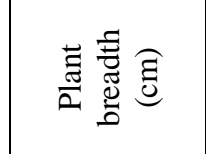 & & 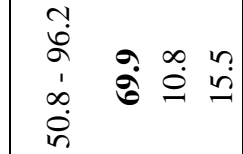 \\
\hline 壳 营莺 & 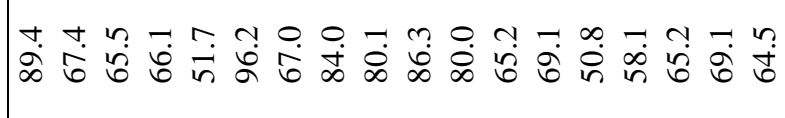 & 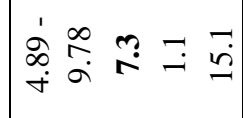 \\
\hline 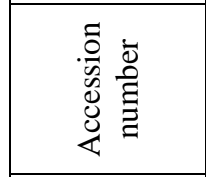 & 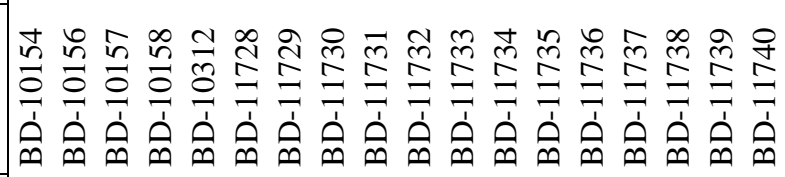 & \\
\hline 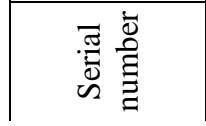 & 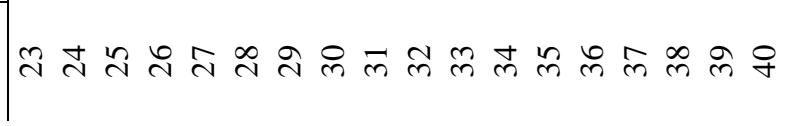 & 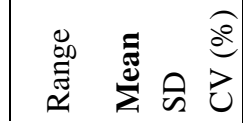 \\
\hline
\end{tabular}


that the accessions within a cluster might have some degree of ancestral relationship. Similar findings were obtained in previous study by Solaimana et al. (2015). The absence of relationship between genetic and geographic diversity suggests that forces other than geographic origin, such as exchange of breeding material, genetic drift, variation, natural and artificial selection are responsible for diversity (Murty and Arunachhalam 1966). The clustering pattern followed their respective geographic origin and variation between clusters might have resulted from the possible genetic drifts and selection. Hassan et al. (2015), Begum et al. (2017) and Solaimana et al. (2015) observed 3, 5 and 6 clusters, respectively.

Table 3. Number of brinjal accessions under different classes

\begin{tabular}{|c|c|c|c|}
\hline Name of descriptor & Descriptor state & $\begin{array}{c}\text { Number of } \\
\text { accession }\end{array}$ & $\begin{array}{l}\text { Percent of } \\
\text { accession }\end{array}$ \\
\hline \multirow{2}{*}{ No. of primary branches per plant } & Intermediate (6-10) & 37 & 92 \\
\hline & Weak (3-5) & 3 & 8 \\
\hline \multirow{2}{*}{ Plant height $(\mathrm{cm})$} & Tall (61-100) & 32 & 80 \\
\hline & Intermediate $(31-60 \mathrm{~cm})$ & 8 & 20 \\
\hline \multirow{2}{*}{ Plant breadth $(\mathrm{cm})$} & Broad $(61-90 \mathrm{~cm})$ & 24 & 60 \\
\hline & Very broad $(91-150 \mathrm{~cm})$ & 16 & 40 \\
\hline \multirow{2}{*}{ Leaf blade Length (cm) } & Intermediate $(11-20 \mathrm{~cm})$ & 38 & 95 \\
\hline & Long $(21-30 \mathrm{~cm})$ & 2 & 5 \\
\hline \multirow{2}{*}{ Leaf blade width (cm) } & Wide $(11-15 \mathrm{~cm})$ & 22 & 55 \\
\hline & Intermediate $(5-10 \mathrm{~cm})$ & 18 & 45 \\
\hline \multirow{3}{*}{ Days to $1^{\text {st }}$ flowering } & Optimum (91-105 days) & 26 & 65 \\
\hline & Late $(>105$ days $)$ & 11 & 27 \\
\hline & Early (<90 days) & 3 & 8 \\
\hline \multirow{3}{*}{ Days to 1 st edible fruiting stage } & Optimum (121-130 days) & 23 & 57 \\
\hline & Late $(>130$ days $)$ & 9 & 23 \\
\hline & Early (<121 days) & 8 & 20 \\
\hline \multirow{4}{*}{ Fruit length $(\mathrm{cm})$} & Long $(11-20 \mathrm{~cm})$ & 22 & 54 \\
\hline & Intermediate $(6-10 \mathrm{~cm})$ & 9 & 23 \\
\hline & Very long $(>20 \mathrm{~cm})$ & 7 & 18 \\
\hline & Short $(3-5 \mathrm{~cm})$ & 2 & 5 \\
\hline \multirow{3}{*}{ Fruit breadth $(\mathrm{cm})$} & Intermediate $(4-5 \mathrm{~cm})$ & 17 & 42 \\
\hline & Large $(6-10 \mathrm{~cm})$ & 13 & 33 \\
\hline & Short $(2-3 \mathrm{~cm})$ & 10 & 25 \\
\hline \multirow{3}{*}{ Fruit weight (g) } & Medium (30-60 g) & 16 & 40 \\
\hline & Low $(<30 \mathrm{~g})$ & 14 & 35 \\
\hline & $\operatorname{High}(>60 \mathrm{~g})$ & 10 & 25 \\
\hline \multirow{5}{*}{ Number. of fruits/plant } & Low $(7-12)$ & 18 & 44 \\
\hline & Very low $(<7)$ & 14 & 35 \\
\hline & Intermediate (13-18) & 4 & 10 \\
\hline & High (19-24) & 3 & 8 \\
\hline & Very high $(>24)$ & 1 & 3 \\
\hline \multirow{3}{*}{ 100-seed weight (g) } & Medium $(0.31-0.40 \mathrm{~g})$ & 25 & 62 \\
\hline & $\operatorname{High}(>0.40 \mathrm{~g})$ & 9 & 23 \\
\hline & Low $(<0.31 \mathrm{~g})$ & 6 & 15 \\
\hline
\end{tabular}


Table 4. Distribution of accessions in five clusters of brinjal

\begin{tabular}{|c|c|c|}
\hline Cluster & $\begin{array}{c}\text { No. of } \\
\text { accession }\end{array}$ & Accessions with their place of collection \\
\hline Cluster-I & 7 & $\begin{array}{l}\text { Panchagarh-BD-7319 and BD-11740; Thakurgaon-BD-7323; } \\
\text { Sherpur-BD-7335; Chittagong-BD-7315; Bandarban-BD- } \\
\text { 11733; Rangamati-BD-11738 }\end{array}$ \\
\hline Cluster-II & 10 & $\begin{array}{l}\text { Rangpur-BD-7327, BD-11726 and BD-10158; Pabna-BD- } \\
\text { 9953;Rajshahi-BD-10312, BD-11734, BD-11735, BD-11736 } \\
\text { and BD-11737; Tangail-BD-7328 }\end{array}$ \\
\hline Cluster-III & 5 & $\begin{array}{l}\text { Rangpur-BD-10154; Chittagong-BD-9954; Rangamati-BD- } \\
\text { 9955; Bandarban-BD-11730; Pabna-BD-11727 }\end{array}$ \\
\hline Cluster-IV & 10 & $\begin{array}{l}\text { Panchagarh-BD-7320; Dinajpur-BD-7324; Rangpur-BD- } \\
\text { 10151, BD-10156 and BD-10157; Barisal-BD-7314; Jamalpur- } \\
\text { BD-7332 and BD-7333; Maulovibazar-BD-9766; Rangamati- } \\
\text { BD-11739 }\end{array}$ \\
\hline Cluster-V & 8 & $\begin{array}{l}\text { Thakurgaon-BD-7321; Rajshahi-BD-7781; Chapai } \\
\text { Nawabganj-BD-9952; Magura-BD-11728; Chittagong-BD- } \\
11729 ; \text { Bandarban-BD-11731 and BD-11732; Pabna- BD- } \\
9838\end{array}$ \\
\hline Total & 40 & \\
\hline
\end{tabular}

Table 5. Intra-and Inter cluster distance of different accessions in brinjal

\begin{tabular}{l|c|c|c|c|c}
\hline Name of character & Cluster-I & Cluster-II & Cluster-III & Cluster-IV & Cluster-V \\
\hline Cluster-I & $\mathbf{0 . 9 8}$ & & & & \\
\hline Cluster-II & 7.91 & $\mathbf{0 . 9 4}$ & & & \\
\hline Cluster-III & 6.18 & 8.32 & $\mathbf{1 . 3 6}$ & & \\
\hline Cluster-IV & 4.16 & 4.01 & 5.23 & $\mathbf{0 . 9 4}$ & \\
\hline Cluster-V & 8.12 & 4.34 & 5.20 & 4.31 & $\mathbf{0 . 9 8}$ \\
\hline
\end{tabular}

Where, Diagonal and bold indicate intra cluster distance

The intra-cluster distance ranged from 0.94 (Clusters II and IV) to 1.36 (Cluster III) (Table 5). This showed cluster III was more heterogeneous than any other clusters. Maximum inter cluster distance was estimated between clusters II and III (8.32) followed by clusters I and V (8.13), suggesting wide diversity between the accessions of these groups. On the contrary, the minimum inter-cluster distance was observed between clusters II and IV (4.01) indicated close relationship (Table 5). 
Table 6. Cluster mean of different characters in brinjal

\begin{tabular}{|l|c|c|c|c|c|}
\hline Name of character & Cluster-I & Cluster-II & Cluster-III & Cluster-IV & Cluster-V \\
\hline Plant height $(\mathrm{cm})$ & 71.91 & $59.32^{*}$ & $84.3^{\star *}$ & 66.63 & 76.35 \\
\hline Plant breadth $(\mathrm{cm})$ & 86.14 & $74.96^{*}$ & $109.9^{* *}$ & 80.63 & 102.12 \\
\hline No. of primary branches per plant & 7.16 & $6.77^{*}$ & $8.66^{* *}$ & 6.91 & 7.78 \\
\hline Leaf blade Length $(\mathrm{cm})$ & $17.07^{* *}$ & 16.24 & 16.46 & $15.69^{*}$ & 16.96 \\
\hline Leaf blade width $(\mathrm{cm})$ & 11.24 & $10.06^{*}$ & 10.92 & 10.06 & $11.35^{* *}$ \\
\hline Days to 1st flowering & $105^{* *}$ & $98^{*}$ & 101 & 102 & 101 \\
\hline Days to 1st edible frutting stage & $128^{* *}$ & $121^{*}$ & 127 & 125 & 125 \\
\hline Fruit length $(\mathrm{cm})$ & 17.07 & $12.16^{*}$ & 16.38 & $17.27^{\star *}$ & 13.25 \\
\hline Fruit breadth $(\mathrm{cm})$ & $3.81^{*}$ & $7.24^{* *}$ & 4.96 & 4.2 & 4.46 \\
\hline Fruit weight $(\mathrm{g})$ & $73.7^{* *}$ & $23.37^{*}$ & 59.39 & 44.79 & 27.49 \\
\hline No. of fruits/plant & 8 & $6^{*}$ & $16^{* *}$ & 12 & 9 \\
\hline 100-seed wt $(\mathrm{g})$ & 0.36 & $0.39^{\star *}$ & 0.35 & 0.35 & $0.34^{*}$ \\
\hline
\end{tabular}
respectively.

The cluster means of different characters are presented in Table 6. Accessions belong to Cluster I had showed the highest leaf blade length, days to first flowering and days to edible fruiting stage, and fruit weight. This cluster showed the lowest fruit breadth. Accessions of Cluster II produced the lowest plant height, plant breadth, number of primary branches, leaf blade length and width, days to first flowering and first edible fruiting stage, fruit length and weight, and number of fruits per plant. This cluster showed the highest mean values for fruit breadth and 100-seed weight. Cluster III had the highest cluster mean values for plant height, plant breadth, number of primary branches per plant and number of fruits per plant. The highest fruit length and the lowest leaf blade length were obtained from cluster-IV. Cluster V exhibited the highest leaf blade width and the lowest of 100 - seed weight. The cluster constellations obtained by $\mathrm{D}^{2}$ analysis were confirmed by canonical analysis. Cluster constellations were also independently derived by using principal component analysis (PCA) to verify grouping obtained through $\mathrm{D}^{2}$ statistic in a two-dimensional chart (PC1-PC2). In principal component analysis $\mathrm{PC} 1, \mathrm{PC} 2$ and $\mathrm{PC} 3$ were observed to contribute $60.68 \%, 34.06 \%$ and $3.42 \%$, respectively of the total divergence. Accession scores obtained for the first two components were plotted on two main axis and then superimposed on the clustering found from $\mathrm{D}^{2}$ analysis (Fig. 2), showed the similar results. The maximum distance was observed between accessions BD7327 (Rangpur) from Cluster II with BD-9954 (Chittagong) from Cluster III, and BD-7319 (Panchagarh) from Cluster I with BD-11732 (Bandarban) from ClusterV (Fig.2). The accessions were comparatively close to each other in cluster II and 
IV, and those in cluster III were most heterogeneous through scatter diagram. The results obtained by principal component analysis were reconfirmed by $\mathrm{D}^{2}$ analysis. Plant populations restricted to small geographic areas or subjected to identical environmental pressures help to evolve adaptive gene complexes. These gene complexes are conserved by genetic linkages or stringent natural or human selections. The clustering of accessions from different ecographic locations into one cluster could be attributed to the free exchange of breeding materials between regions (Solaimana et al. 2015). The magnitude of heterosis and potential for transgressive segregation largely depend on the degree of genetic diversity in the parental lines. The greater the distance between two clusters, the wider the scope of genetic diversity between their accessions. This suggested that selection of parents for hybridization should be done from two clusters having wider intercluster distances to get more variability among the segregants. But while considering genetic diversity among the parents to be included in a hybridization programme their yield potentiality should not be ignored.

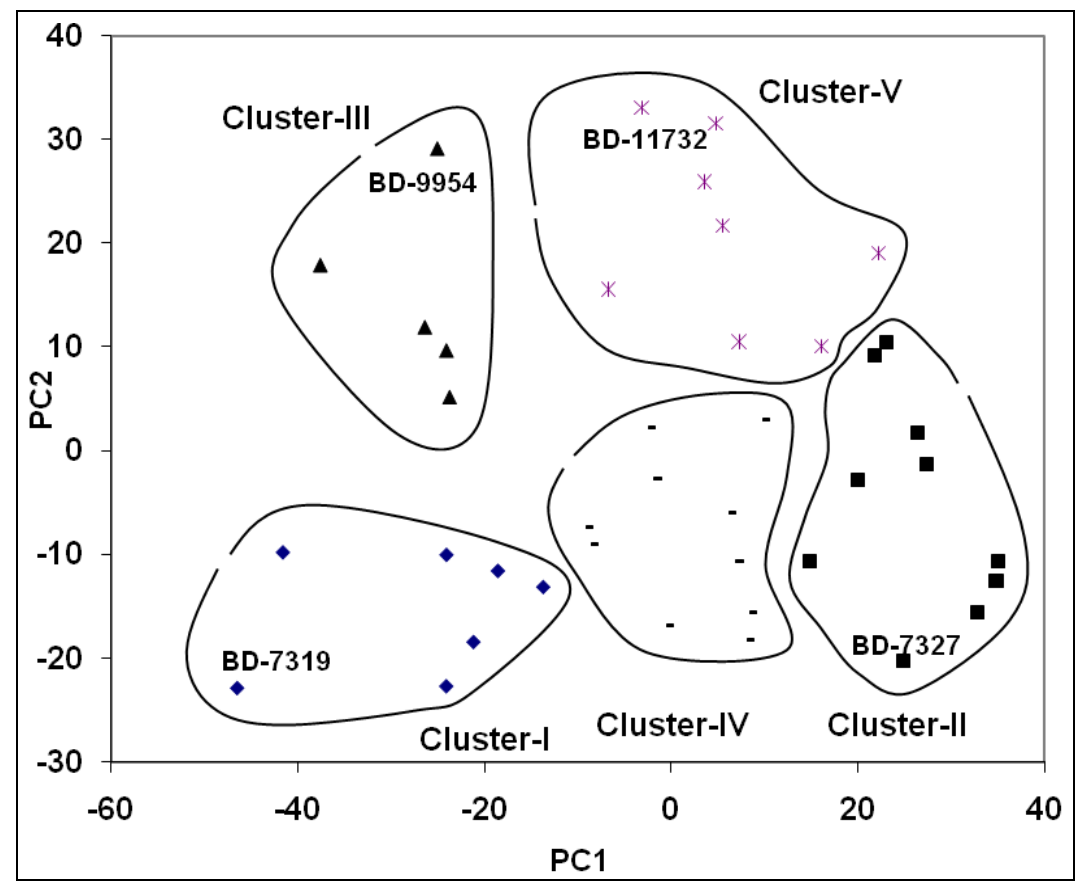

Fig. 2 Principal component analysis of the genetic diversity of $\mathbf{4 0}$ brinjal accessions with 5 clusters, where PC1 and PC2 principal component1 and principal conponent 2 , respectively.

On the basis of cluster analysis and different qualitative characters, the accessions could be selected, BD-7315, BD-7335, BD-9766, BD-10154 and BD10158 as elongate fruit; BD-11726, BD-7327, BD-9953, BD-9954, BD-10312 and BD-11737 as broad fruit; BD-7319, BD-11733, BD-7335, BD-7323, BD- 
7315, BD-11730 and BD-11740 as maximum fruit weight; BD-9955, BD-10154, BD-10151, BD-10156, BD-7320 and BD-11727 as maximum number of fruits.

\section{Conclusion}

Variations were found among the qualitative characters like plant growth habit, leaf blade lobing, leaf prickles, flower colour, fruit curvature, fruit shape, fruit apex shape, fruit colour, fruit colour distribution. A good range of variations were found among the 12 quantitative characters. The maximum coefficient of variations was found in number of fruits per plant (57.99\%) and minimum in days to first edible fruiting stage (6.68\%). The 40 accessions were grouped into five clusters. Genetic diversity of the accessions did not show clear relationship with their place of collection. The crosses should be made between the accessions in cluster II with accessions in cluster III, and accessions in cluster I with accessions in cluster V. The selected accessions could be used for varietal development of brinjal.

\section{References}

Azad A. K., B. K. Goswami, M. L. Rahman, P. K. Malaker, M. S. Hasan and M H. H Rahman. 2017, Edited Krishi Projukti Hatboi (Handbook on Agro-technology), $7^{\text {th }}$ edition Bangladesh Agricultural Research Institute, Gazipur 1701, Bangladesh. Pp 143-156.

BBS (Bangladesh Bureau of Statistics) 2011. Year Book of Agricultural Statistics, Ministry of Planning, Government of the People's Republic of Bangladesh, Dhaka. Pp.138-148.

Begum M. N. S., B. J. Shirazy, M. M. Mahbub and M. A. Siddikee. 2017. Performance of brinjal (Solanum melongena) genotypes through genetic variability analysis. American J. of Plant Biol. 3(1): 22-30.

Demir K., M. Bakr, G. Sarkamş and S. Acunalp. 2010. Genetic diversity of eggplant (Solanum melongena) germplasm from Turkey assessed by SSR and RAPD markers. Genet. Mol. Res. 9(3): 1568-1576.

FRG. 2012. Fertilizer Recommendation Guide. Bangladesh Agricultural Research Council, Farmgate, New Airport road, Dhaka-1205. P.118.

Kumar G., B. L. Meena, R. Kar, S. K. Tiwari, K. K. Gangopadhyay, I. S. Bisht and R. K.Mahajan.2008.Morphological diversity in brinjal (Solanum melongena L.) germplasm accessions. Plant Genetic Resour.: Characterization and Utilization 6(3):232-236.

Hassan I., S. A. Jatoi, M. Arif, S. U. Siddiqui and M. Ahson. 2015. Genetic Variability in Eggplant for Agro-Morphological Traits. Science, Technology and Development 34(1): 35-40.

Hawkes, J. G. 1983. The diversity of crop plants. Harvard Univ. Press, London. 184 P.

IBPGR.1990. Descriptors for Eggplant. International Board for Plant Genetic Resources, Rome, Italy. Pp. 8-23. 
Islam, M. S. and M. S. Uddin. 2009. Genetic variation and trait relationship in the exotic and local eggplant germplasm. Bangladesh J. Agric. Res., 34: 91-96.

Khorsheduzzaman A. K. M, M. Z. Alam, M. M Rahman, M. A. K Mian, M. I. H Mian and M. M. Hossain. 2008. Molecular characterization of five selected brinjal (Solanum melongena L) genotypesusing SSR markers. Bangladesh J. Genet Pl. Breed., 21(1): 01-06.

Murali S., S. K. Jalali, A. N. Shylesha and T. M. S. Swamy. 2017. Molecular Characterization and their Phylogenetic Relationship Based on Mitochondrial Cytochrome Oxidase I of Brinjal Shoot and Fruit Borer, Leucinodes orbonalis (Guenée) (Lepidoptera: Pyralidae). Int. J. Curr. Microbiol. App. Sci (2017) 6 (7): 2527-2539.

SCA (Seed Certification Agency). 2018. http://sca.gov.bd/site/files/ 7dee0533-035c49a2-98ed-4f69f7df44f7/Approved-\&-Registered-Crop-variety, Date 29.5.2018

Solaimana A. H. M., T. Nishizawa, M. Khatun and S. Ahmad. 2015. Physiomorphological characterization genetic variability and correlation studies in brinjal genotypes of Bangladesh. Computational and Mathematical Biology. 4(1): 137.2015

Sunseri F., G. B. Polignano, V. Alba, C. Lotti, V. Bisignano, G. Mennella, A. D' Alessandro M. Bacchi, P. Riccardi, M. C. Fiore and L. Ricciard. 2010. Genetic diversity and characterization of African eggplant germplasm collection. African $J$. Plant Sci. Vol. 4(7): 231-241

Thomas T. A. and P. N. Mathur. 1991. Germplasm evaluation and utilization. In: R.S. Paroda and R.K. Arora. (eds.). Plant Genetic Resources Conservation and Management, IBPGR, Regional Office, New Delhi-11012, India. Pp.149-181.

Upadhyaya, H. D., C.L.L. Gowda and D.V.S.S.R. Sastry, 2008. Plant genetic resources management:Collection, characterization, conservation and utilization. J. SAT Agric. Res., 6: 1-16. 